\title{
KS-103: High Yielding, Leaf Rust Tolerant and Resistant to Pest Complex Soybean Variety for Southern Zone
}

\author{
S. R. Shinde, M. S. Kamble* and A. R. Aher \\ Agricultural Botany Division, Rajarshee Chhatrapati Shahu Maharaj College of Agriculture, \\ Kolhapur- 416104 (M.S.) India \\ *Corresponding author
}

\section{A B S T R A C T}

Keywords

Soybean, Leaf rust, tolerance, Grain yield

Article Info

Accepted:

10 July 2020

Available Online:

10 August 2020
KS-103, a new soybean variety developed from the cross JS-335 x EC-241780 at Agricultural Botany Division, RCSM College of Agriculture, Kolhapur (Mahatma Phule Krishi Vidyapeeth, Rahuri, Maharashtra) identified in annual group meeting held at Jorhat (Assam ) for Southern Zone comprising Maharashtra A.P. , Karnataka and Tamil Nadu with IC number- IC 613905. The Variety is released on the basis of high Yield-25.37 q/ha. (Average yield of co-ordinated trials for South Zone) and better leaf rust tolerance compared to existing varieties. The variety KS-103 is having 12.4 gms 100 grain wt. For development of this variety back cross $\left(\mathrm{BC}_{2}\right)$ method was followed by pedigree method. It is non lodging and fertilizer responsive recommended for irrigated and rain fed ecology of Kharif Season of South Zone and early maturity group which takes 91-95 days for maturity. This variety is also suitable for late sown conditions i.e. up to end of June. As far as reaction to diseases and pests is concerned, it is having better field rust tolerance and resistant to pest complex. The plant height of the genotype was $61.23 \mathrm{~cm}$. The genotype KS-103 was taller than JS-335 with semi-erect growth habit and more spreading than check variety JS-335. Recommended seed rate for this variety is $75 \mathrm{~kg} / \mathrm{ha}$. The grains are yellowish white with 18.10 per cent oil and 45.56 per cent protein. The variety is superior in yield over check varieties viz. Bragg, RKS-18 and MAUS-61 and qualified varieties DSB-20 and RKS-63. The growth habit of the variety is semi-determinate and takes 39 days for 50 per cent flowering. Leaf shape round ovate with dark green colour. Flower is violet, leaf and pod pubescence is absent. Pod colour at maturity is brown and seed shape is rounded with light brown hilum colour.

\section{Introduction}

Soybean has an important place in world's oilseed cultivation scenario, due to its high productivity, profitability and vital contribution towards maintaining soil fertility. The crop also has a prominent place as the world's most important seed legume, which contributes $25 \%$ to the global vegetable oil production, about two thirds of the world's protein concentrate for livestock feeding and is a valuable ingredient in formulated feeds for poultry and fish. The major soybean producing nations are the United States, 
Brazil and Argentina. The three countries dominate global production, accounting for $80 \%$ of the world's soybean supply. Soybean contributes significantly to the Indian edible oil pool. Presently soybean contributes $43 \%$ to the total oilseeds and $25 \%$ to the total oil production in the country. Currently, India ranks fourth in respect to production of soybean in the world. (FICCI). Production of soybean in India is dominated by Maharashtra and Madhya Pradesh which contribute 89 per cent of the total production. Rajasthan, Andhra Pradesh, Karnataka, Chhattisgarh and Gujarat contribute the remaining 11 per cent production. During Kharif 2019 in Maharashtra the area was 37.365 million ha, productivity $1055 \mathrm{~kg} / \mathrm{ha}$ and production 39.415 milliom meteric tons. (SOPA, Databank, 2019)

Soybean [Glycine $\max$ (L.) Merill] is an important food legume and plays vital role in human livelihood. It contains high quality of proteins (40\%) and edible oil (20\%) containing major essential amino acids. Soybean meal acting as high quality protein source for livestock feed rations (Mary et al., 2013). It is the world's most important seed legume, which contributes to $25 \%$ of the global edible oil, about two-thirds of the world's protein concentrate for livestock feeding (Agarwal et al., 2013). Pest and disease management are an important aspects of obtaining higher soybean yield and it contributes 72 per cent of all the constraints studied. It was observed that 70 per cent of the farmers were unaware of the sucking and leaf eating pests attacking the soybean and their control measures. Likewise, 99 per cent respondents expressed that there was unavailability of pest and disease resistant variety seeds. Charlotte et al. (2015) reported that the pest and diseases are the major determinants in the soybean production system. The most effective way to prevent the occurrence of this disease is to develop genetically resistant cultivars (Mahalingam et al., 2018). Hence, KS-103 was developed to identify a high yielding new variety with tolerant to leaf rust disease.

\section{Materials and Methods}

The locally adapted, high yielding but susceptible to leaf rust variety JS-335 and rust resistant variety EC-241780 were used as parents in hybridisation programme. The progenies obtained through this cross were backcrossed with EC-241780 ( $\left(\mathrm{BC}_{2}\right)$ followed by pedigree selection (Partial backcross method) were adopted for development of rust resistant variety. Selection of the progenies resistant / tolerant to rust combined with high yield were selected from $\mathrm{BC}_{2} \mathrm{~F}_{2}$ population onward. These progenies were evaluated in University, State multi-location trial and Co-ordinated Varietal Trials in south zone. The leaf rust resistance reaction were confirmed artificially at field level in rust prone area i.e. Sangli, Maharashtra. Sowing time is $1^{\text {st }}$ Fortnight of June using seed rate 75 $\mathrm{kg} / \mathrm{ha}$ with spacing- $45 \times 10 \mathrm{~cm}$. The fertilizer doses 50:75:00 NPK Kg/ha is applied to this variety. Pest resistance was confirmed through field screening in Co-ordinated trials. Based on the yield superiority and rust tolerance in coordinated trial, it was identified for release as KS-103 in AICRP workshop held at Jorhat, Assam for southern zone comprises of Maharashtra, Karnataka, Andra Pradesh, and Tamil Nadu. The DNA profile of KS-103 is also carried out at State Level Biotechnology Centre, MPKV Rahuri (Maharashtra).

\section{Results and Discussion}

As far as comparative performance of KS-103 and other genotypes under IVT of south zone are concerned the genotype KS-103 recorded second highest yield performance. The trials were conducted at seven different locations 
under south zone. In AVT-I trials conducted at 6 different locations in south zone, the genotype KS-103 recorded seed yield of 2418 $\mathrm{kg} / \mathrm{ha}$ and ranked forth. In AVT-II trials conducted at 6 different locations in south zone, the genotype KS-103 recorded seed yield of $2126.19 \mathrm{~kg} / \mathrm{ha}$ and ranked second. The performance was compared with three checks varieties and four qualified varieties.

The genotype KS-103 had given mean seed yield of $2537 \mathrm{Kg} / \mathrm{ha}$. The yield performance of the genotype was superior and shown 16.7, 15.7and 26.7 per cent yield increase over the mean yield of check varieties viz. Bragg, RKS-18 and MAUS-6 while, 3.4, 4.1 and 7.7 per cent over the qualifying varieties DSB-20, MACS-1311 and RKS-63 respectively (Table 1).

As the reaction to the major disease like leaf rust is concerned, the genotype KS-103 performed well and given 80, 100, 3.3, 51.1 and 55.5 score in different coordinated trials conducted at different locations during 201011 to 2012-13. The genotype KS-103 comes under the tolerant category considering the average reaction to leaf rust is concerned (Table 2).

Reaction to major pests was concerned the genotype shown moderately resistant to resistant reaction for defoliators, leaf rollers and per cent stem tunnelling stem fly. Moderately resistant reaction was recorded for damage per cent pod and resistant to highly susceptible reaction for leaf minor.

The low resistance was recorded by the genotype KS-103 for infection of blue beetle. In general the genotype KS-103recorded resistance to major pest complex of soybean (Table 3).

Considering the overall yield performance, tolerant reaction to soybean rust and resistant reaction to soybean pest complex, the genotype KS-103 was recommended for release for the south zone of India comprising of the states Maharashtra, Karnataka, Andra Pradesh, and Tamil Nadu.

For present study 16 different ISSR primers were used to analyse polymorphism between KS-103 and other genotypes, so in future it will useful to identity the genotypic diversity of KS-103 at molecular level. The three important ISSR primers (ISSR-842, ISSR885, ISSR-888) which showed good polymorphism are presented herewith (PlateII).

The three primers showed seven to eight amplified fragments ranging from 190bp to 1000 bp. The specific 490bp and 520bp polymorpic bands in ISSR-885, >1000bp polymorphic bands in ISSR-888 and 950bp polymorpic bands in ISSR-842 were missing in KS-103.

In conclusion the asian soybean rust caused by Phakopsora pachyrhizi Syd. is one of the most threatening diseases of soybean in major soybean production areas around the world.

In spite of the availability of chemical control with fungicides, the increase in production costs as well as operational difficulties and health hazards associated with fungicide usage for disease management has prompted the search for development of durable resistance to $P$. pachyrhizi.

It is a major problem especially in southern parts of India causing significant yield losses ranging from 30 to 100 per cent. Most of the popular cultivars like JS 335 is highly susceptible to rust in India. Under these circumstances, the most effective and long term strategy would be breeding resistant cultivars or incorporating resistance into popular susceptible cultivars. 
Table.1 Summary yield data of KS-103 and other genotypes under Coordinated Varietal Trials of Southern zone

\begin{tabular}{|c|c|c|c|c|c|c|c|c|c|c|}
\hline & $\begin{array}{l}\text { Year of } \\
\text { Testing }\end{array}$ & $\begin{array}{l}\text { No. of } \\
\text { Trials }\end{array}$ & $\begin{array}{l}\text { Mean Yield of } \\
\text { Proposed } \\
\text { Variety q/ha } \\
(\text { KS-103) }\end{array}$ & $\begin{array}{c}\text { CV.1 } \\
\text { (Bragg) }\end{array}$ & $\begin{array}{l}\text { CV.2 } \\
\text { (RKS- } \\
\text { 18) }\end{array}$ & $\begin{array}{l}\text { CV. } 3 \\
\text { (MAUS- } \\
\text { 61) }\end{array}$ & $\begin{array}{l}\text { QV.1 } \\
\text { (KDS- } \\
\text { 344) }\end{array}$ & $\begin{array}{l}\text { QV. } 2 \\
\text { (DSb- } \\
\text { 20) }\end{array}$ & $\begin{array}{c}\text { QV.3 } \\
\text { (MACS- } \\
\text { 1311) }\end{array}$ & $\begin{array}{c}\text { QV.4 } \\
\text { (RKS- } \\
\text { 63) }\end{array}$ \\
\hline \multirow{4}{*}{$\begin{array}{l}\text { Mean yield (q/ha) } \\
\text { a) Zonal } \\
\text { b) Across Zones (It applicable) }\end{array}$} & 2010 & 7 & 2990 & 2411 & 2423 & 2076 & 2765 & 2760 & 2662 & 2733 \\
\hline & 2011 & 6 & 2418 & 2165 & 2064 & 1912 & 2593 & 2406 & 2467 & 2151 \\
\hline & 2012 & 6 & 2126 & 1879 & 2025 & 2006 & 2310 & 2120 & 2109 & 2114 \\
\hline & Mean & 19 & 2537 & 2184 & 2184 & 2002 & 2567 & 2446 & 2413 & 2333 \\
\hline \multirow{3}{*}{$\begin{array}{l}\text { Percentage increase or decrease } \\
\text { over checks \& qualifying varieties }\end{array}$} & 2010 & 7 & - & 24.0 & 23.4 & 44.0 & 8.1 & 8.3 & 12.3 & 9.4 \\
\hline & 2011 & 5 & - & 11.7 & 17.2 & 26.5 & -6.7 & 0.5 & -2.0 & 12.4 \\
\hline & 2012 & 6 & - & 13.1 & 5.0 & 6.0 & -8.0 & 0.3 & 0.8 & 0.6 \\
\hline $\begin{array}{l}\text { Percentage increase of } \mathrm{KS}-103 \\
\text { over mean yield of checks \& } \\
\text { qualifying varieties }\end{array}$ & - & - & - & 16.7 & 15.7 & 25.7 & -1.7 & 3.4 & 4.1 & 7.7 \\
\hline Frequency in the top group & - & - & - & 17.1 & 16.1 & 26.7 & -1.2 & 3.7 & 4.6 & 7.8 \\
\hline
\end{tabular}

Table.2 Reaction to major diseases

\begin{tabular}{|c|c|c|c|c|c|c|c|c|c|c|}
\hline Sr. No. & $\begin{array}{c}\text { Disease } \\
\text { Name }\end{array}$ & Item & Year & $\begin{array}{c}\text { Proposed Variety } \\
\text { KS-103 }\end{array}$ & $\begin{array}{c}\text { CV. } 1 \\
\text { (Bragg) }\end{array}$ & $\begin{array}{c}\text { CV. } 2 \\
(\mathrm{RKS}-18)\end{array}$ & $\begin{array}{c}\text { CV. } 3 \\
\text { (MAUS-61) }\end{array}$ & $\begin{array}{c}\text { QV.1 } \\
(\text { KDS-344) }\end{array}$ & $\begin{array}{c}\text { QV. } 2 \\
(\mathrm{DSb}-20)\end{array}$ & $\begin{array}{c}\text { QV.3 } \\
\text { (RKS-63) }\end{array}$ \\
\hline \multirow[t]{3}{*}{1.} & \multirow[t]{3}{*}{ Leaf rust } & \multirow[t]{3}{*}{ NAT } & 2010-11 & $80,100,3.3$ & $86.6,100$ & 80,100 & $62.02,100$ & $\begin{array}{l}\text { NG 55.6, } \\
23.7\end{array}$ & $\begin{array}{c}65.6,77.8 \\
16.7\end{array}$ & $\begin{array}{c}88.9,100, \\
78\end{array}$ \\
\hline & & & $2011-12$ & 51.1 & 85.9 & 73.7 & 69.5 & 57.5 & 67.5 & 65.7 \\
\hline & & & $2012-13$ & 55.5 & 51.1 & 55.5 & 51.1 & 44.4 & 51.1 & 51.1 \\
\hline
\end{tabular}


Table.3 Reaction to major pests

\begin{tabular}{|c|c|c|c|c|c|c|c|c|c|c|}
\hline $\begin{array}{l}\text { Sr. } \\
\text { No. }\end{array}$ & $\begin{array}{c}\text { Pest } \\
\text { Name }\end{array}$ & Item & Year & $\begin{array}{c}\text { Proposed } \\
\text { Variety } \\
(\text { KS-103) }\end{array}$ & $\begin{array}{c}\text { CV-1 } \\
\text { (Bragg) }\end{array}$ & $\begin{array}{c}\text { CV-2 } \\
(\text { JS-335) }\end{array}$ & $\begin{array}{c}\text { CV-3 } \\
\text { (MAUS- } \\
61)\end{array}$ & $\begin{array}{l}\text { QV-1 } \\
\text { (KDS- } \\
\text { 344) }\end{array}$ & $\begin{array}{c}\text { QV-2 } \\
(\mathrm{DSb} 20)\end{array}$ & $\begin{array}{c}\text { QV-3 } \\
\text { (RKS- } \\
\text { 63) }\end{array}$ \\
\hline \multirow[t]{3}{*}{1.} & \multirow[t]{3}{*}{ Defoliators } & \multirow[t]{3}{*}{ NAT } & 2010-11 & MR & MR & HS & -- & MR & MR & MR \\
\hline & & & 2011-12 & $\mathrm{R}$ & MR & $\mathrm{S}$ & $\mathrm{R}$ & $\mathrm{S}$ & $\mathrm{HS}$ & $\mathrm{S}$ \\
\hline & & & $2012-13$ & $\mathrm{R}$ & $\mathrm{S}$ & S & $\mathrm{S}$ & $\mathrm{R}$ & $\mathrm{R}$ & S \\
\hline \multirow[t]{2}{*}{2.} & \multirow[t]{2}{*}{ Leaf roller } & \multirow[t]{2}{*}{ NAT } & $2010-11$ & $\mathrm{R}$ & $\mathrm{R}$ & -- & -- & $\mathrm{R}$ & $\mathrm{R}$ & $\mathrm{R}$ \\
\hline & & & $2012-13$ & MR & HS & $\mathrm{R}$ & $\mathrm{R}$ & MR & HR & LR \\
\hline 3. & Blue beetle & NAT & $2010-11$ & LR & LR & LR & -- & LR & LR & MR \\
\hline \multirow[t]{2}{*}{4.} & \multirow[t]{2}{*}{ Leaf minor } & \multirow[t]{2}{*}{ NAT } & $2011-12$ & $\mathrm{R}$ & $\mathrm{R}$ & $\mathrm{R}$ & -- & $\mathrm{S}$ & $\mathrm{R}$ & $\mathrm{S}$ \\
\hline & & & $2012-13$ & HS & $\mathrm{R}$ & MR & $\mathrm{R}$ & HS & $\mathrm{R}$ & HS \\
\hline \multirow[t]{2}{*}{5.} & \multirow{2}{*}{$\begin{array}{l}\text { damage \% } \\
\text { Pod }\end{array}$} & \multirow[t]{2}{*}{ NAT } & $2011-12$ & MR & MR & -- & -- & $\mathrm{R}$ & MR & MR \\
\hline & & & $2012-13$ & MR & MR & LR & -- & MR & $\mathrm{R}$ & $\mathrm{S}$ \\
\hline \multirow[t]{2}{*}{6.} & \multirow{2}{*}{$\begin{array}{l}\text { \% Stem } \\
\text { tunneling } \\
\text { Stem fly }\end{array}$} & \multirow[t]{2}{*}{ NAT } & $2011-12$ & MR & MR & MR & -- & MR & HR & LR \\
\hline & & & $2012-13$ & $\mathrm{R}$ & MR & LR & -- & MR & MR & MR \\
\hline
\end{tabular}




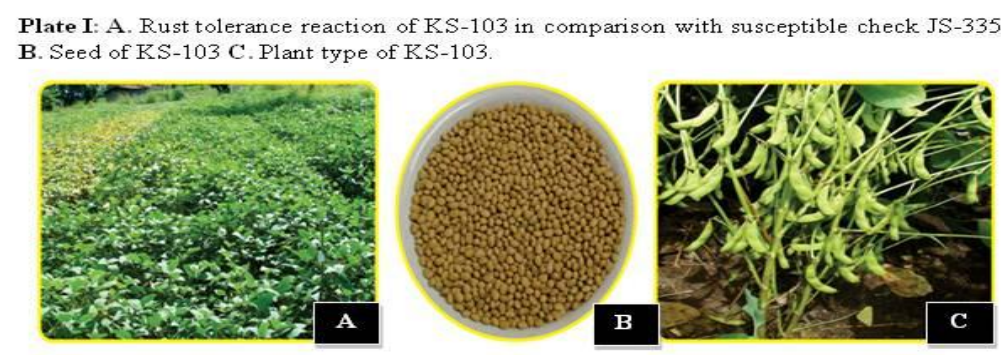

Plate II: ISSR primer based DNA polymorphisms of soybean genotypes.
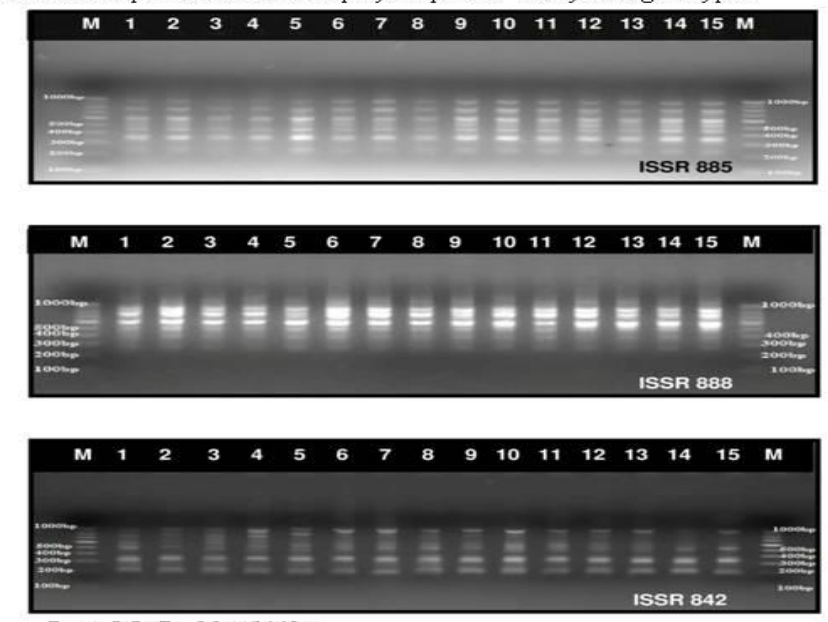

\begin{tabular}{|c|c|c|c|c|c|}
\hline \multicolumn{6}{|c|}{$L$ ane $M=L$ adder $100 b_{p}$} \\
\hline L ane $\mathrm{No}$. & Genotype & L ane No. & Genotype & L ane $N_{0}$. & Genotype \\
\hline 1 & $\mathrm{KS}-103$ & 6 & JS -335 & 11 & Monetta \\
\hline 2 & $\mathrm{KS}-106$ & 7 & KDS-739 & 12 & Kalitur \\
\hline 3 & $\mathrm{KS}-112$ & 8 & NRC-94 & 13 & Birsa Soya \\
\hline 4 & KS -128 & 9 & KDS -722 & 14 & DS-9712 \\
\hline 5 & DS -228 & 10 & MAUS -71 & 15 & MACS 45 \\
\hline
\end{tabular}

Keeping these things in view, a long term breeding programme was initiated at the Agricultural Botany Division, RCSM College of Agriculture, Kolhapur (Mahatma Phule Agricultural University, Rahuri), Maharashtra, India to develop rust resistant / tolerant genotypes. For this purpose the rust resistant germplasm EC 241780 was utilized in hybridization with agronomically superior but rust susceptible cultivar JS 335. Out of 582 advanced breeding lines developed from these cross were screened under natural epiphytotic condition as well as artificially inoculated glass house condition. One line from the cross JS 335 x EC 241780 (KS 103) exhibited tolerant reaction with high yield potentiality for more than six years at hot spots for rust. Under rust prone condition, this genotypes recorded more than 150 per cent increased seed yield compared to the popular and best check JS 335. Further, there was significant per cent higher yield respectively over JS 335 in All India Coordinated Trials over years (2010-12). Owing to its rust tolerance, high yield and resistance to pest complex and early maturity KS-103 has been released and notified for Southern Zone of India during 2013. This genotype is having yield superiority in addition to rust tolerance and resistance to pest complex and early maturity over JS 335. Definitely, this variety is a boon to soybean growing farmers by preventing significant yield losses due to soybean rust and pest complex of soybean. 


\section{Acknowledgement}

Thankful to Wheat Rust Mycologist, ARS, Mahabaleshwar (MPKV, Rahuri Maharashtra) for supply seed of soybean rust resistant genotype EC-241780 and Officer Incharge, State level Biotechnology Centre, MPKV, Rahuri for DNA finger printing analysis.

\section{References}

Agarwal, D. K., Billore, S. D., Sharma, A. N., Dupare, B. U. and Srivastava, S. K. (2013). Soybean: Introduction, Improvement, and Utilization in IndiaProblems and Prospects. Agric. Res. 2(4): 293-300.

Charlotte Carmelle Zoundji, Pascal
Houngnandan, Houinsou Dedehouanou and Fatiou Toukourou. (2015). Determinants of Soybean

Mahalingam A, V.K. Satya, N. Manivannan, S. Lakshmi Narayanan and P. Sathya. (2018). Inheritance of Mungbean Yellow Mosaic Virus Disease Resistance in Greengram (Vigna radiata (L.) Wilczek). Int. J. Curr. Microbiol. App. Sci., 7(1): 880-885.

Mary Lubungu, William Burke, and Nicholas J. Sitko. (2013). Challenges of Smallholder Soybean Production and Commercialization in Eastern Province of Zambia. Indaba Agricultural Policy Research Institute, Policy Brief, Number 62.

\section{How to cite this article:}

Shinde, S. R., M. S. Kamble and Aher, A. R. 2020. KS-103: High Yielding, Leaf Rust Tolerant and Resistant to Pest Complex Soybean Variety for Southern Zone. Int.J.Curr.Microbiol.App.Sci. 9(08): 893-899. doi: https://doi.org/10.20546/ijcmas.2020.908.097 